J. Japan. Assoc. Min.

Petr. Econ. Geol.

69, $332-338,1974$

\title{
TITANO-PENNINITE FROM THE PHLOGOPITE-BEARING ULTRAMAFIC ROCKS IN THE UFU-SAN ULTRAMAFIC BODY, THE MIKABU ZONE, CENTRAL JAPAN.
}

\author{
Michiya Inomata and Hiroshi Tateyama
}

Geological and Mineralogical Institute, Tokyo University of Education, Otsuka, Bunkyo-hu, Tokyo, Japan.

\section{INTRODUGTION}

Many ultramafic complexes are distributed in the Mikabu zone in the Sambagawa metamorphic belt, south-west Japan. Some of these ultramafic complexes contain a trace amount of phlogopite-bearing ultramafic rocks. In the previous paper the phlogopites from the Kurouchi-yama, the Tonmaku-yama and the Ufu-san ultramafic bodies were described (Inomata and Tazaki, 1974; Tazaki and Inomata, 1974). These phlogopites are characterized by high titanium content but frequently altered into penninite and serpentine minerals. Although there are not so many chemical data about penninite, they show that penninite usually contains less than 1 weight per cent of $\mathrm{TiO}_{2}$, whereas the penninite investigated here has very high $\mathrm{TiO}_{2}$ content such as 2.34 per cent.

The aim of this paper is to present the chemistry and some physical properties of the titano-penninite altered from the phlogopite in the Ufu-san ultramafic body and to discuss some relationships between titano-penninite and phlogopite in the Mikabu ultramafic rocks.

\section{Mode of Ocgurrence of Titano- PENNINITE}

The Ufu-san ultramafic body is in the
Mikabu zone (Fig. 1) and mainly composed of dunite, wehrlite, clinopyroxenite, hornblendite and gabbro. The wehrlite and hornblende-clinopyroxenite have a trace amount of phlogopite (Inomata and Tazaki, 1974) and the titano-penninite probably altered from phlogopite is contained in the same rock types, most of which are partially or completely serpentinized, serpentine minerals frequently showing pseudomorph after olivine and clinopyroxene. The mineral assemblages of the titanopenninite bearing ultramafic rock are shown in the following section. As the phlogopite content of the ultramafic rocks is usually less than 1 volume per cent, the amount of titano-penninite altered from phlogopite

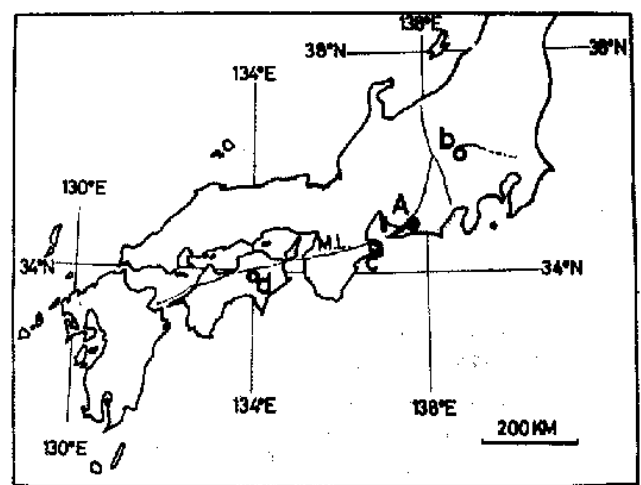

Fig. 1. Index map.

A; the Ufu-san. b; the Kurouchi-yama.

c; the Toba d; the Orono.

M.L.; Median tectonic line. 


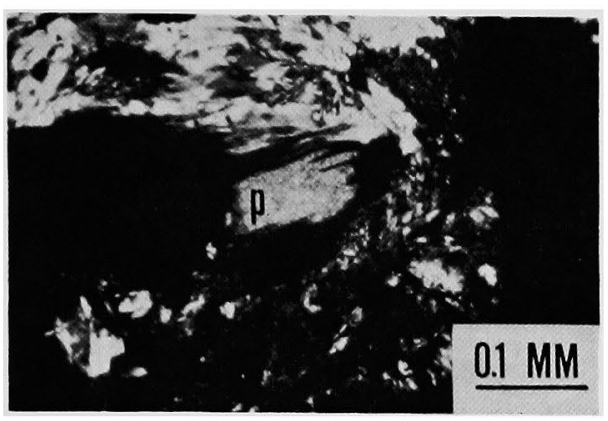

Fig. 2. Photomicrograph of titano-penninite. P: titano-penninite. Crossed-nicols

is very scarce. The titano-penninite is frequently intergrown with phlogopite along the cleavages, and sometimes coexists with serpentine minerals. In addition, it shows sometimes a pseudomorph after phlogopite. The size of titanopenninite is less than $0.10 \mathrm{~mm}$ and irregular in shape. The pleochroism is $Z=$ coffee brown, $X=$ colorless to pale brown. Although titanopenninite is dusty when opaque minerals are included in it, the analysis was performed at the clear part. A photomicrograph of the titano-penninite is shown in Fig. 2.

\section{DESGRIPTION OF THE SPEGIMEN 345.}

Clinopyroxene; anhedral, serpentinization going along the cleavages. Pargasite; anhedral, the size less than $0.1 \mathrm{~mm}$. Tremolite; irregular shape, $\mathrm{c} \wedge Z=20^{\circ}$, colorless, the size less than $0.3 \mathrm{~mm}$. Sphane; irregular shape, small grains less than $0.1 \mathrm{~mm}$, weakly pleochroic. Serpentine minerals; mesh structure, partially pseudomorph after olivine and clinopyroxene. Chromite; euhedral, partially enclosed by magnetite rim, the size about $1 \mathrm{~mm}$. Magnetite; anhedral irregular shape, acicular magnetite scattered in serpentine minerals, sometimes enclosing chromite. Pyrite and Chalcopyrite; scattered in ser- pentine minerals, the size less than 0.05 $\mathrm{mm}$.

\section{Experimental Teghniques}

\section{Electron Microprobe Analysis}

A sample is analyzed in carbon-coated polished thin section with a Japan Electron Optics Laboratory electron probe microanalyzer Model JXA-5A of the Institute for Thermal Spring Research, Okayama University. The analytical procedures were described in detail by Inomata and Tazaki (1974), and a natural mica was used as a working standard. Operating conditions were as follows: accelarating potential, 15 $\mathrm{kV}$; specimen current, $0.02 \mu \mathrm{A}$; electron beam diameter, $5 \sim 6$ microns. The determinations were reproducible within narrow limits. The accuracy was estimated at \pm 5 per cent of the amount of present. $X$-ray Single Crystal Diffraction Study

Although the cell parameters are usually determined with the X-ray powder diffraction method, we used Rotaion and Weissenberg X-ray cameras, because of the very scarce and small sample. A single crystal was picked up by a glass fiber from the thin section under the microscope. Because the diffraction spots were very diffuse, the parameters could not be determined precicely.

\section{Results AND Discussion}

a) Unit Cells

By the single-crystal X-ray diffraction method, the cell dimentions are obtained as follows;

$$
\begin{aligned}
& \mathrm{a}_{0}=5.36 \AA \AA \\
& \mathrm{b}_{0}=9.28 \AA \mathrm{A}, \\
& \mathrm{c}_{0}=14.45 \dot{\mathrm{A}}, \\
& \beta=97^{\circ} .
\end{aligned}
$$

The b-parameter is calculated from $a_{0}$ by the relation $b_{0}=a_{0} \sqrt{ } \overline{3}$, because the rotation 
Table 1. Observed $|F|(002)$ values for penninite and vermiculite

$\begin{array}{llc} & \text { Penninite } & \text { Vermiculite }^{2} \\ 002 & \text { I F l }\left.\right|_{\text {obs. }} & \text { I F } \text { J }_{\text {obs. }} \\ 002 & 10.92 & 10.92 \\ 003 & 10.08 & 32.76 \\ 004 & 18.40 & 31.92 \\ 005 & 5.98 & 80.64\end{array}$

1 : This study.

2 : Tateyama et al. (1972).

Table 2. Chemical composition and structural formula of a titanopenninite

$\begin{array}{lclc}\mathrm{SiO}_{2} & 34.77 & \mathrm{Si} & 6.556(6.414) \\ \mathrm{TiO}_{2} & 2.34 & \mathrm{Al}(\mathrm{IV}) & 1.444(1.586) \\ \mathrm{Al}_{2} \mathrm{O}_{3} & 13.32 & \mathrm{Al}(\mathrm{VI}) & 1.516(1.309) \\ \mathrm{FeO}\left(\mathrm{Fe}_{2} \mathrm{O}_{3}\right) & 8.16(8,98) & \mathrm{TI} & 0.332(0.325) \\ \mathrm{MnO} & 0.24 & \mathrm{Fe} & 1.288(1.247) \\ \mathrm{MgO} & 30.01 & \mathrm{Mn} & 0.038(0.038) \\ \mathrm{CaO} & 0.02 & \mathrm{Mg} & 8.439(8.255) \\ \mathrm{Na}_{2} \mathrm{O} & 0.03 & \mathrm{Ca} & 0.004(0.004) \\ \mathrm{K}_{2} \mathrm{O} & 0.07 & \mathrm{Na} & 0.011(0.011) \\ \mathrm{Total} & 88.96(89.78) & \mathrm{K} & 0.017(0.017) \\ & & \mathrm{z} & 8.00(8.00) \\ & & \mathrm{X}+\mathrm{Y} & 11.61(11.17) \\ & & \mathrm{W} & 0.03(0.03)\end{array}$

Iron assumed to be ferrous in first column and ferric in second column. Formula has been calculated on the basis of 28 oxygen equivalents. Titano-penninite from the specimen 345 .

photograph (b-axis rotation) shows very diffuse spots.

Although we cannot distinguish penninite from vermiculite only by the cell parameters, observed $|\mathrm{F}|(00 l)$ values draw a clear distinction between them as is shown in Table 1 . On the basis of the equation $\mathrm{d}(001)=14.55-0.29 \mathrm{X}$ (Brindley, 1960 , p. 290), deducing $X=0.72$, the estimated tetrahedral ions are $\left(\mathrm{Si}_{3.28} \mathrm{Al}_{0.72}\right)$, whereas the relation cruve between basal spacing $\mathrm{d}(001)$ and tetrahedral $\mathrm{Al}$ content in natural chlorites (Shirozu, 1958) gives
$\left(\mathrm{Si}_{3.28} \mathrm{Al}_{0.78}\right)$.

b) Chemistry

The result of the microprobe analysis is tabulated in Table 2, with the structural formula based on $0=28$ calculated for both cases of total $\mathrm{Fe}$ as $\mathrm{FeO}$ and as $\mathrm{Fe}_{2} \mathrm{O}_{3}$ because the ratio $\mathrm{Fe}^{2+} / \mathrm{Fe}^{3+}$ could not be obtained by a microprobe analysis. When a formula is calculated on the basis of 28 oxygen equivalents, however, total number of octahedral ions is somewhat shorter of ideal twelve for total $\mathrm{Fe}$ as $\mathrm{Fe}_{2} \mathrm{O}_{3}$ than as $\mathrm{FeO}$. Accordingly, it is reasonable to assume that all iron ions in this penninite should be treated as ferrous ions. Although the analyzed titano-penninite falls in typical penninite field of the Hey (1954)'s diagram (Fig. 3), it is characterized by high $\mathrm{TiO}_{2}$ content (2.34 per cent). Iron content in this penninite is slightly high (Fig. 3).

The number of tetrahedral ions calculated from the chemical analysis is $\left(\mathrm{Si}_{\mathbf{3 . 2 B}}\right.$ $\mathrm{Al}_{0.72}$ ). The content of $\mathrm{Al}$ determined by $\mathrm{X}$ -

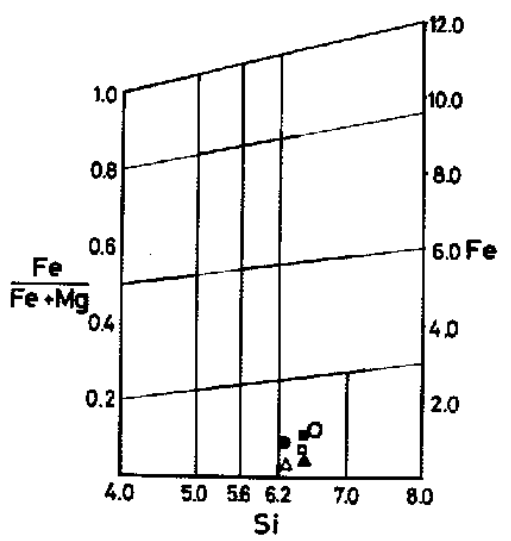

Fig. 3. Si-Fe-Mg relation diagram after $\mathrm{Hey}$ (1954).

Open circle; this study. Solid circle; Eckhardt (1958). Open square; Tschermak (1891). Solid square; Montoya and Baur (1963). Open triangle; Trommsdorff and Evans (1969). Solid triangle; Varadarajan (1964) 
Table 3. Chemical composition and structural formula of a phlogopite

$\begin{array}{lrll}\mathrm{SiO}_{2} & 40.45 & \mathrm{Si} & 5.727 \\ \mathrm{TiO}_{2} & 3.65 & \mathrm{Al} & 2.267 \\ \mathrm{Al}_{2} \mathrm{O}_{3} & 13.59 & \mathrm{Ti} & 0.389 \\ \mathrm{FeO}^{2} & 8.30 & \mathrm{Fe} & 0.984 \\ \mathrm{MnO} & 0.08 & \mathrm{Mn} & 0.009 \\ \mathrm{MgO} & 21.66 & \mathrm{Mg} & 4.574 \\ \mathrm{Ca} & - & \mathrm{Ca} & - \\ \mathrm{Na}_{2} \mathrm{O} & 2.23 & \mathrm{Na} & 0.612 \\ \mathrm{~K}_{2} \mathrm{O}^{2} & 5.46 & \mathrm{~K} & 0.986 \\ \mathrm{Tota1} & 95.42 & 2 & 8.00 \\ & & \mathrm{Y} & 5.95 \\ & & \mathrm{X} & 1.60\end{array}$

1 ; Phlogopite from wehrlite (Inomata and Tazaki, 1974).

2; Total $\mathrm{Fe}$ as $\mathrm{FeO}$.

Formula has been calculated on the basis of 22 oxygen equivalents.

\section{Table 4}

$\begin{array}{ll}\text { Serpentine(Chrysotile) } & \mathrm{Mg}_{3} \mathrm{Si}_{2} \mathrm{O}_{5}(\mathrm{OH})_{4} \\ \text { Penninite } & \mathrm{Mg}_{5} \mathrm{Al}_{2} \mathrm{SI}_{3} \mathrm{O}_{10}{ }^{(\mathrm{OH})_{8}} \\ \text { Phlogopite } & \mathrm{KMg}_{3} \mathrm{AlSI}_{3} \mathrm{O}_{10}{ }^{(\mathrm{OH})_{2}} \\ \text { Olivine } & \mathrm{Mg}_{2} \mathrm{SiO}_{4}\end{array}$

ray determinative curve (Shirozu, 1958) shows somewhat high value $(\mathrm{Al}=0.78)$, but close to one estimated by Brindley (1960)'s equation. Therefore it is conceivable that all titanium ions may enter not into tetrahedral site but into octahedral ones in this titano-penninite. This fact is also supported by chemical properties of aluminum as favourring tetrahedral sites and the charge balance of ions on this titano-penninite. This suggests that all titanium ions of phlogopites from the Ufu-san body (Inomata and Tazaki, 1974) may also be in octahedral sites (Table 3). c) Relationships among Titano-penninite, Serpentine and Phlogopite in the Mikabu Ultramafics

Serpentinization of ultramafic rocks has been studied by many workers (Hostether et al., 1966; Coleman, 1969; Wenner and Taylor, 1971; Barnes and O'neil, 1969). According to their studies, it seems likely that most of serpentinites were formed in the temperature range from $100^{\circ} \mathrm{C}$ to $500^{\circ} \mathrm{C}$. Phlogopite, serpentine and titano-penninite belong to $\mathrm{Mg}$-layered silicate minerals and have similar chemical composition excepting for potassium. For convenience, these minerals were written as in Table 4, treating $\mathrm{MgO}$ as $\mathrm{MgO}+\mathrm{FeO}$. Titano-penninite is plotted near the join of amesite and chrysotile on the molecular per cent composition diagram showing phases in the quarternary system $\mathrm{MgO}-\mathrm{Al}_{2} \mathrm{O}_{3}-\mathrm{SiO}_{2}-\mathrm{H}_{2} \mathrm{O}$ with composition projected on the anhydrous base (Fig. 4). Roy and Roy (1954), Nelson and Roy (1958) and Fawcett and Yoder (1966) have already treated in this system concerned. The experimental study by Yamanaka and Bodine (1971) was performed on septechlorite at the temperature range of serpentinization. They showed that penninite is stable at the temperature range from $300^{\circ} \mathrm{C}$ to $400^{\circ} \mathrm{C}$, and the pressure higher than 5000 psi. in the chemical environment of the ratio $\mathrm{KCl} / \mathrm{MgCl}_{2}=1$, and the range from $300^{\circ} \mathrm{C}$ to $350^{\circ} \mathrm{C}$, and pressure higher than 7500 psi. in the chemical environment of the ratio $\mathrm{KCl} / \mathrm{MgCl}_{2}=100$, and that the stability field of penninite increases with decreasing of the ratio $\mathrm{KCl} / \mathrm{MgCl}_{2}$.

Accordingly in the ultramafic rocks, penninite has somewhat wide stability field. The penninite investigated here is not a septechlorite but a $14 \AA$ chlorite, therefore, the above experimental results are unable to be applied in this case. Recently Velde 
(1973) studied on this system from a point of view of solid solution series of chlorites and associated minerals, and compared to natural chlorites and serpentines. He suggested that the phase relations in the simplified synthetic system are applicable to natural minerals assemblages within some limits. The $14 \AA$ chlorites are stable above $300^{\circ} \mathrm{C}$ at $1 \mathrm{~Kb}$ and $400^{\circ} \mathrm{C}$ at $2 \mathrm{~Kb}$, and Fig. 4 shows the solid solution limit observed at various temperatures and $2 \mathrm{~Kb}$ pressure for the $14 \AA$ chlorites (Velde, 1973). The limit may move slightly in the case of natural chlorites with some amounts of iron and other minor elements and increase with decreasing of pressure.

Plotting the titano-penninite reported here on the diagram, it falls near the boundary of the solid solution limit above $515^{\circ} \mathrm{C}$ at $2 \mathrm{~Kb}$. Although it is still ambiguous where ultramafic rocks were serpentinized, it seems not so deep. As mentioned previously, the titano-penninite has some amounts of iron and titanium, therefore, the formation of it might be done at the temperature range from $400^{\circ} \mathrm{C}$ to $500^{\circ} \mathrm{C}$, and may be shown by the following serpentinization reaction;

$2 \mathrm{~K}(\mathrm{Mg}, \mathrm{Ti})_{3} \mathrm{AlSi}_{3} \mathrm{O}_{10}(\mathrm{OH})_{2}+7 \mathrm{Mg}_{2} \mathrm{SiO}_{4}+$ phlogopite olivine

$12 \mathrm{H}_{2} \mathrm{O} \longrightarrow(\mathrm{Mg}, \mathrm{Ti})_{5} \mathrm{Al}_{2} \mathrm{Si}_{8} \mathrm{O}_{10}(\mathrm{OH})_{8}+$ added titano-penninite

$5 \mathrm{Mg}_{3} \mathrm{Si}_{2} \mathrm{O}_{5}(\mathrm{OH})_{4}+\mathrm{K}_{2} \mathrm{O}$

serpentine removed

Titanium ions in phlogopites may be fixed tightly in octahedral sites, so that they remained in octahedral ones during serpentinization, resulting in the formation of the titano-penninite. Although the introduction of abundant water such as weathering makes phlogopite to alter into vermiculite generally, it is hardly formed under the condition of limited amount of water as

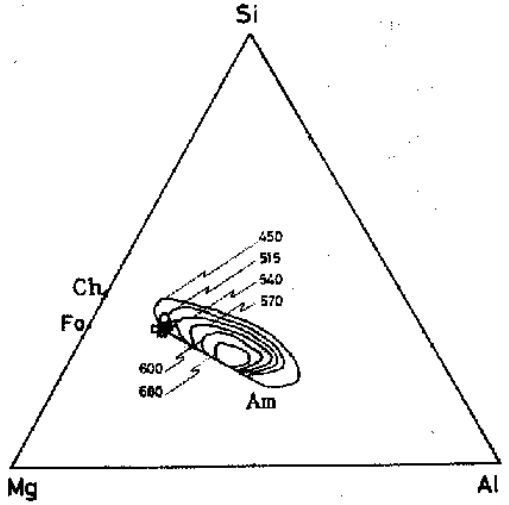

Fig. 4. Si-Al-Mg relation diagram Notation are the same as those in Fig. 3. Contours show solid solution limits observed at various temperatures and $2 \mathrm{~Kb}$ for the $14 \AA$ chlorites (Velde, 1973). Ch: chrysotile, Fo: forsterite. Am: Amesite.

serpentinization.

It has already been reported that the Kurouchi-yama in the northern Kanto mountains, the Ufu-san and the Tonmakuyama bodies, which are all in the Mikabu zone, contain trace amounts of phlogopitebearing ultramafic rocks. The observation of the rock thin sections shows that the ultramafic rocks from the Kurouchi-yama (phlogopite-bearing) and from the Orono region, Tokushima prefecture in Shikoku (also in the Mikabu zone, Fig. 1) contain similar penninite (perhaps altered from phlogopites). This suggests that similar titano-penninite may be found in the Toba ultrabasic complex, also in the Mikabu zone, which contains mica-bearing peridotites (Fig. 1. Nakamura, 1971).

\section{ACKNOWLEDGEMENTS}

A part of this study was carried out at the Institute for Thermal Spring Research of Okayama University, the writers wish to acknowledge to Dr. K. Tazaki and other members of the institute for providing tus 
the opportunity to use an electron microprobe. They wish also to express their thanks to Professor Masao Gorai of Tokyo University of Education to Dr. K. Kimbara of Geological Survey of Japan and to Dr. K. Tazaki of Okayama University for their valuable suggestions and critical reading of the manuscript. Our thanks are also due to Professor Toshio Sudo of Tokyo University of Education for critical reading of this paper with much improvements. This study was in part supported by the Grant-in-Aid for Scientific Research, Ministry of Education.

\section{REFERENCES}

Barenes, I. and O'neil, J.R. (1969), The relationship between fluids in some fresh Alpine-type ultramafics and possible modern serpentinization, Western United States. Geol. Soc. Amer. Bull., 80, 1947-1960.

Brindley, G.W. (1960), X-ray identification and crystal structures of clay minerals, 2nd ed. Mineral. Soc. London.

Coleman, R.G. (1971), Petrologic and geophysical nature of serpentinites. Geol. Soc. Asnev. Bull., 82, 897-918.

Eckhardt, F.J. (1958), Uber Chlorite in Sedimenten. Geol. Jb., 75, 437-473.

Fawcett, J.J., and Yoder, H.S. (1966), Phase relationships of chlorites in the system $\mathrm{MgO}-\mathrm{Al}_{3} \mathrm{O}_{8}$ $\mathrm{SiO}_{2}-\mathrm{H}_{2} \mathrm{O}$. Amer. Mineral., 51, 353-380.

Hey, M.H. (1954), A new review of the chlorites. Mineval. Mag., 30, 277-292.

Hostetler, P.B., Coleman, R.G., Mumpton, F.A. and Evans, B.W. (1966), Brucite in Alpine serpentinites. Amer. Mineral., 51, 75-98.

Inomata, M. and Tazaki, K. (1974), Phlogopite and Tipargasite-bearing ultramafic rocks from the Mikabu zone, central Japan. J. Japan. Assoc. Min. Pet. Econ. Geol., 69, 205-214.

Montoya, J.W. and Baur, G.S. (1963), Nikeliferous serpentines, chlorites and related minerals found in two lateritic ores. Amer. Mineral., 48, 1227-1238.
Nakamura, Y. (1971), Petrology of the Toba ultrabasic complex, Mie prefecture, central Japan. J. Fac. Sci., Univ. Tokyo, Sec. II, 18, 1-51.

Nelson, B.W. and Roy, R. (1958), Synthesis of the chlorites and their structural and chemical constitution. Amer, Mineral., 43, 707-725.

Roy, D.M. and Roy, R. (1954), An experimental study of the formation and properties of synthetic serpentines and related layered silicate minerals. Amer. Mineral., 39, 957-975.

Shirozu, H. (1958), X-ray powder patterns and cell dimentions of some chlorites in Japan, with a note on their interference colors. Mineral. J., 6, 209-223.

Tateyama, H., Shimoda, S. and Sudo, T. (1972), Artificial alteration of a common hornblende into clay minerals by hydrothermal conditions. J. Japan. Assoc. Min. Pet. Econ. Geol., 67, 35-44.

Tazaki, K. and Inomata, M. (1974), Phlogopite and pargasite in wehrlites from the northern Kanto mountains. Paper Inst. Thermal Spring Reseavch, Okayama Univ., 43, 1-13

Trommsdorff, V. and Evans, B.W.(1969), The stable association enstatite-forsterite-chlorite in amphibolite facies ultramafics of the Leopontine Alps. Schw. Mineval. Petrogr., 49, 325-332.

Tschernak, G. (1891), Die Chloritgruppe. Sitzber. Akad. Wiss. Wien, 100, 29, cited in Rock-forming minerals, Vol, 3., 144 (Ed. Deer, W.A., Howie, R.A. and Zussman, J.).

Varadarajan, S. (1964), A chrome-nikel pennine from serpentine, Janbur chromite mines, Mysore state, India. Amer. Mineval., 49, 420424.

Velde, B. (1973), Phase equilibria in the system $\mathrm{MgO}-\mathrm{Al}_{2} \mathrm{O}_{3}-\mathrm{SiO}_{2}-\mathrm{H}_{2} \mathrm{O}$ : chlorites and associated minerals. Mineval. Mag., 39, 297-312.

Werner, D.B., and Taylor, H.P. (1971), Temperatures of serpentinization of ultramafic rocks based on $\mathrm{O}^{18} / \mathrm{O}^{18}$ fractionation between coexisting serpentine and magnetite. Contr. Mineral. and Petrol., 32, 165-185.

Yamanaka, T., and Bodine, M.W. (1971), Synthesis of septechlorite solid solution and its equilibrium relation with phlogopite. Mineral. J., 6 , 383-404. 


\section{御荷針带雨生山超塩基性岩体の含金雲母超苦鉄啠岩中の}

Titano-penninite について

猪俣道也・立山博

雨生山岩体の含金雲母超苦鉄澌中の Titano-penninite について化学分析値，単位格子、 $|F|$ 値が得られた。 Titanium 多く含む penninite は今まで知られていない。ところが, この penninite は, 2.34 wt. 9 の TiO 量を示し，異常なるのであることがかかった。このことは, phlogopite から交質してでさたことに由来すると 推定される。また，御荷鋒带の超苦鉄質岩の Titano-penninite， serpentine，phlogopite の関係纪ついて若干の 議諭をした。

$\begin{array}{ll}\text { Ufu-san } & \text { 雨生山 } \\ \text { Kurouchi-yama } & \text { 黑内山 } \\ \text { Toba } & \text { 鳥 羽 } \\ \text { Orono } & \text { 鬼籠野 }\end{array}$

